DOI https://doi.org/10.30525/978-9934-26-179-4-23

\title{
СУДОВИЙ ЗАХИСТ ПЕНСІЙНИХ ПРАВ ПРАЦІВНИКІВ ПРАВООХОРОННИХ ОРГАНІВ ЯК ГАРАНТІЯ КОНСТИТУЦІЙНОГО ПРАВА НА СОЦІАЛЬНИЙ ЗАХИСТ
}

\begin{abstract}
Князькова Л. М.
кандидат юридичних наук, дочент, доцент кафедри загально-правових дисциплін

Донецьький державний університет внутрішніх справ

м. Маріуполь, Донечька область, Украӥна

Хайлова Т. В.

кандидат наук з державного управління, доцент,

дочент кафедри державно-правових дисииплін та публічного управління Донещький державний університет внутрішніх справ м. Маріуполь, Донещька область, Україна

Згідно статті 6 Конвенції про захист прав і основоположних свобод «кожен має право на справедливий і публічний розгляд його справи упродовж розумного строку незалежним i безстороннім судом, встановленим законом, який вирішить спір щодо його прав та обов'язків цивільного характеру або встановить обгрунтованість будьякого висунутого проти нього кримінального обвинувачення» [1]. Право на оскарження в суді рішень, дій чи бездіяльності органів державної влади, органів місцевого самоврядування, посадових i службових осіб також передбачено ч.1 статті 55 Конституції України [2]. Гарантоване конституційне право на оскарження в суді закріплено i спеціальним законодавством щодо пенсійного забезпечення працівників правоохоронних органів, а саме: статтею 66 Закону України «Про пенсійне забезпечення осіб, звільнених 3 військової служби, та деяких інших осіб». Ця стаття передбачає, що рішення про відмову в призначенні пенсії або іiі перерахунку, зарахуванні до вислуги років для призначення пенсії окремих періодів служби в календарному обчисленні або на пільгових умовах, порушення строків і заниження розмірів пенсії може бути оскаржено до вищих органів або до суду [3]. Цілком погоджуємось 3 думкою судді Верховного суду Берназюк Я., що право на соціальний захист у всіх формах є гарантованим Конституцією України та невідчужуваним особистим правом, яке, за загальним правилом, має абсолютний характер (не залежить від внесення змін до законів або фінансових
\end{abstract}


можливостей держави) [4]. Виходячи 3 предметної юрисдикції адміністративних судів, визначеної статті 19 Кодекс адміністративного судочинства України, справи, пов'язані із захистом соціальних прав громадян (в тому числі - пенсійних), розглядаються у порядку адміністративного судочинства [5]. В аналітичному огляді стану здійснення правосуддя у 2020 році, проведеному Державною судовою адміністрацією, відмічене, що до адміністративних судів надійшло у 457 тисяч справ упродовж року, що на 22\% більше ніж у попередньому році. Серед справ, які розглядали окружні адмінсуди, справи зі спорів 3 приводу реалізації публічної політики у сфері соціального захисту громадян становили $45,2 \%$ (80240 справ). Крім того, за рік кількість розглянутих справ цієї категорії зросла на $61 \%$ порівняно з минулим роком. Причому пенсійні справи складають приблизно $20 \%$ від загальної кількості, що розглядається даним судом [6]. Тому проблема, яка розглядається $\epsilon$ актуальною для дослідження як науковцями так $\mathrm{i}$ практиками. Безперечно, що важливим показником досягнутого суспільством і державою рівня цивілізованості у сучасному світі є ступінь забезпеченості прав і свобод особи, особливо у соціальній сфері.

Слід відзначити, що працівники правоохоронних органів з 01.01.2016 року відстоюють свої права щодо перерахунку пенсій спочатку у зв'язку з реорганізацією міліції та створенням нової інституції - Національної поліції України, а 3 - 01.12.2019 року у зв'язку зі збільшенням грошового забезпечення поліцейським. У листопаді 2019 року грошове забезпечення поліцейських було підвищено, а саме: була введена надбавка поліцейським за особливості проходження служби та змінився розмір премій поліцейським. У зв'язку з тим, що Міністерство внутрішніх справ України не направило до органів Пенсійного фонду України оновлених довідок про грошове забезпечення для перерахунку пенсій у відповідності зі ст. 63 вищезазначеного Закону, пенсіонери органів внутрішніх справ почали звертатися до суду з позовами про видачу оновлених довідок про грошове забезпечення станом на 01.12.2019 року. Таких справ накопичилось у судах досить багато. Органи Пенсійного Фонду України відмовляють у проведенні перерахунку пенсій за різними підставами, в тому числі за відсутністю коштів, необхідних для перерахунку пенсій. Такі підстави у відмовах перерахунку пенсій вважаємо необгрунтованими. Адже Велика Палата Верховного Суду визнала необгрунтованими посилання Пенсійного Фонду України на необхідність виділення з Державного бюджету України коштів в обсязі 42,2 млрд. гривен як на підставу відмови в задоволенні позову, оскільки 94 
гарантовані законом виплати, пільги тощо неможливо поставити в залежність від видатків бюджету [7]. Крім того, Конституційний Суд України у своєму Рішенні від 7 листопада 2018 року № 9-p/2018 зазначив : «зміни законодавства у соціальній сфері, складна фінансово економічна ситуація, потреба в забезпеченні збалансованості Державного бюджету України не повинні призводити до порушення гідності людини, яка належить до фундаментальних цінностей, захищених Конституцією України, та становить основу системи конституційного захисту прав і свобод людини і громадянина» [8]. Крім того, Конституційний Суд дотримується позиції, що гарантії соціального захисту осіб, що перебувають на службі у Збройних Силах України та в інших військових формуваннях, а також членів їхніх сімей, потребують більш високого рівня правового захисту.

Так Конституційний Суд зазначив, що «норми-принципи частини п’ятої статті 17 Конституції України щодо забезпечення державою соціального за-хисту громадян України, які перебувають на службі у Збройних Силах України та в інших військових формуваннях, а також членів їхніх сімей, є пріоритетними та мають безумовний характер; тобто заходи, спрямовані на забезпечення державою соціального захисту вказаної категорії осіб, у зв'язку, зокрема, з економічною доцільністю, соціально-економічними обставинами не можуть бути скасовані чи звужені» [9].

Невирішеною проблемою до теперішнього часу $\epsilon$ також невиконання рішень судів. Заборгованість, за рішеннями національних судів, боржниками, в яких $є$ органи Пенсійного Фонду України, становить 867,5 млн грн. [10].

Таким чином, вважаємо, що з урахуванням рішень Верховного Суду у зразкових справах, рішень Конституційного Суду України 3 питань пенсійного забезпечення військовослужбовців та працівників органів внутрішніх справ, а також скасувань в судовому порядку окремих постанов Кабінету Міністрів України з питань пенсійного забезпечення працівників органів внутрішніх справ Пенсійному Фонду України слід провести розрахунки щодо видатків, необхідних для виплати їм належного розміру пенсій та звернутися до Міністерства фінансів України для врахування показників Державного бюджету на 2022 рік.

\section{Література:}

1. Конвенція про захист прав i основоположних свобод, ратифікована Законом України від 17.07.1997 року № 475/97-BP. URL: https://zakon.rada.gov.ua/laws/show/995_004\#Text. 
2. Конституція України: Закон України від 28.06.1996 № 254к/96BP. URL: https://zakon.rada.gov.ua/laws/show/254\%D0\%BA/96-\%D0\% B2\%D1\%80\#Text.

3. Про пенсійне забезпечення осіб, звільнених з військової служби, та деяких інших осіб: Закон України від 09.04.1992 № 2262-XII. URL: https://zakon.rada.gov.ua/laws/show/2262-12\#Text.

4. Берназюк Я. Темпоральні межі захисту соціальних прав. Соиіальні права та їх захист Адміністративним судом : матеріали III Міжнародної науково практичної конференції 5-6 липня 2020, м. Київ. С. 154 С. 150-157.

5. Кодекс адміністративного судочинства України: Закон України від 06.07.2005 № 2747-IV (станом на 05.08.2021). URL: https://zakon.rada.gov.ua/laws/show/2747-15\#Text.

6. Олена Осіпова. Наслідки реформи 2017: розширення юрисдикції чи задуха від справ. Газета Закон $i$ бізнес. URL: https://zib.com.ua/ua/148904naslidki_procesualnoi_reformi2017_rozshirenn ya_yurisdikcii_html (дата звернення 29.09.2021).

7. Постанова Великої Палати Верховного Суду по справі № 160/8324/19 від 24.06.20 р. Єдиний реєстр судових рішень: URL: http://reyestr.court.gov.ua/ (дата звернення 30.09.2021 p.).

8. Рішення Конституційного Суду України від 7 листопада 2018 року № 9-p/2018. URL: https://zakon.rada.gov.ua/laws/show/ v009p710-18\#Text.

9. Рішення Конституційного Суду України від 20 грудня 2016 року № 7-pп/2016. URL: https://zakon.rada.gov.ua/laws/show/v007p710-16.

10. Капінус Є. Діяльність органів пенсійного Фонду України з реалізації гарантій держави щодо виконання рішень суду як складової розподілу соціального блага. Соціальні права ma їх захист Адміністративним судом : матеріали III Міжнародної науково практичної конференції 5-6 липня 2020, м. Київ. С. 50-52. 